\title{
Inhibitory Effects of Mulberry Leaf Extract on Postprandial Hyperglycemia in Normal Rats
}

\author{
Chieko MiYAHARA ${ }^{1}$, Maki MrYAZAWA ${ }^{1, *}$, Shuji SATOH ${ }^{1}$, Anri SAKAI ${ }^{2}$ and Shigenobu MizUSAKI ${ }^{2}$ \\ ${ }^{1}$ Department of Food and Drug, Kanagawa Prefectural Public Health Laboratories, 1-1-1 Nakao, Asahi-ku, \\ Yokohama 241-0815, Japan \\ ${ }^{2}$ Toyotama Healthy Food Co., Ltd., 1-38-12 Kakigaracho, Nihonbashi, Chuo-ku, Tokyo 103-0014, Japan
}

(Received March 31, 2003)

\begin{abstract}
Summary We examined the inhibitory effects of aqueous ethanol extract from mulberry leaves (ME) on postprandial hyperglycemia in normal Wistar rats. ME dose-dependently suppressed the postprandial rise of blood glucose in rats, when ME $(0.02-0.5 \mathrm{~g} / \mathrm{kg})$ was given $0.5 \mathrm{~h}$ before the administration of carbohydrates such as sucrose, maltose and starch. The ME dose showing $50 \%$ inhibition of the increment of blood glucose $\left(\mathrm{ED}_{50}\right)$ was $0.11 \mathrm{~g} / \mathrm{kg}$ for sucrose, $0.44 \mathrm{~g} / \mathrm{kg}$ for maltose, and $0.38 \mathrm{~g} / \mathrm{kg}$ for starch. ME and its basic fraction (MB) containing 1-deoxynojirimycin were assayed for their inhibitory effects $\left(\mathrm{IC}_{50}\right)$ on disaccharidase derived from the small intestine of rats. The $\mathrm{IC}_{50}$ value of $\mathrm{ME}$ was $3.2 \mu \mathrm{g} / \mathrm{mL}$ for sucrase, $10 \mu \mathrm{g} / \mathrm{mL}$ for isomaltase, and $51 \mu \mathrm{g} / \mathrm{mL}$ for maltase. The $\mathrm{IC}_{50}$ value of $\mathrm{MB}$ was $0.36 \mu \mathrm{g} / \mathrm{mL}$ for sucrase, $1.1 \mu \mathrm{g} / \mathrm{mL}$ for isomaltase, and $6.2 \mu \mathrm{g} / \mathrm{mL}$ for maltase. The $\mathrm{IC}_{50}$ value of 1-deoxynojirimycin as the principle component in ME was $0.015 \mu \mathrm{g} / \mathrm{mL}$ for sucrase and $0.21 \mu \mathrm{g} /$ $\mathrm{mL}$ for maltase, and this value was comparable to the $\mathrm{IC}_{50}$ of voglibose. The inhibitory activity of ME in $\alpha$-amylase was weak. These results suggest that ME strongly suppresses postprandial hyperglycemia after carbohydrate loading by inhibiting the activity of disaccharidases in the small intestine of rats.
\end{abstract}

Key Words mulberry leaf, Wistar rat, antipostprandial hyperglycemia, disaccharidase inhibitor, 1-deoxynojirimycin

Mulberry leaves have long been used as a traditional medicine for the treatment and prevention of diabetic mellitus in China $(1,2)$. In Japan, however, mulberry leaves have been used only for tea in some regions such as sericulture areas, and there have been only a few studies on their anti-diabetic effects. Recent studies have shown that mulberry leaves or their extracts possess antihyperglycemic effects in streptozotocin-induced or spontaneous diabetic animals after short-term ip injection (1) or feeding for middle or long-term continuous administration $(3,4)$. It has also been reported that 1-deoxynojirimycin (DNJ) isolated from mulberry root bark suppressed postprandial hyperglycemia in rats and exhibited potent $\alpha$-glucosidase inhibition (5). Mulberry leaves have been shown to have inhibitory effect on $\alpha$ glucosidase, and contain nitrogen-containing sugars such as DNJ as their active component $(2,6)$. However, the antipostprandial hyperglycemic activities of mulberry leaf extract administered only once have rarely been reported, and it is therefore important to elucidate the antipostprandial hyperglycemic properties of mulberry leaves in relation to their inhibitory effect on disaccharidase for utilization as food materials.

In Japan, due to the Westernization of the diet and insufficient exercise, patients with diabetic mellitus have been markedly increasing. The estimated number

*To whom correspondence should be addressed.

E-mail: miyazawa.c2q0@pref.kanagawa.jp of diabetic patients, including latent patients, is over 13,700,000 and most have type 2 diabetes mellitus (NIDDM) (7). Postprandial hyperglycemia strongly stimulates insulin secretion, which imposes an excessive burden on $\beta$ cells of the islets of Langerhans in the pancreas, resulting in the exhaustion of $\beta$ cells (8). For blood glucose control, the inhibition of carbohydrate degradation/absorption in the small intestine is effective, and $\alpha$-glucosidase inhibitors that inhibit carbohydrate hydrolases are clinically used as anti-diabetic agents $(9,10)$. In this respect, the inhibition of postprandial hyperglycemia may be effective not only for the treatment but also for the prevention of diabetes mellitus.

The objective of this study was to investigate the effects of an aqueous ethanol extract from mulberry leaves (ME) and its basic fraction (MB) on the activities of intestinal $\alpha$-glucosidases (EC 3.2.1.20) and human saliva-derived $\alpha$-amylase (EC 3.2.1.1) in vitro and to evaluate the effects of ME in vivo on postprandial hyperglycemia using normal rats.

\section{MATERIALS AND METHODS}

Preparation of $M E$ and $M B$. Dry mulberry leaves (Morus alba L. $35 \mathrm{~kg}$ ) were extracted with $50 \%$ ethanol (304 L) by stirring for $2 \mathrm{~h}$, and filtered to remove insoluble substances. The extracts were concentrated at less than $50^{\circ} \mathrm{C}$ in vacuo and lyophilized to give ME $(6.82 \mathrm{~kg})$. To separate MB, $200 \mathrm{~g}$ of ME was dissolved in $800 \mathrm{~mL}$ of 
distilled $\mathrm{H}_{2} \mathrm{O}$ and chromatographed on an Amberlite IR$120 \mathrm{~B}\left(\mathrm{H}^{+}\right.$form $)$column $(60 \times 350 \mathrm{~mm})$. After washing the column with distilled $\mathrm{H}_{2} \mathrm{O}$, the adsorbed material was eluted with $2 \mathrm{~N} \mathrm{NH}_{4} \mathrm{OH}$ solution $(4 \mathrm{~L})$. The eluted fraction was concentrated in vacuo to give MB $(24 \mathrm{~g})$. DNJ was determined as a fluorenyl-methylchloroformate derivative by a modified method of Cole et al. (11) and its content was $1.10 \%$ in ME and $6.32 \%$ in MB.

Isolation of DNJ. ME was fractionated according to the method of Asano et al. (6). ME (2 kg) was dissolved in $8 \mathrm{~L}$ of distilled $\mathrm{H}_{2} \mathrm{O}$. Chromatography was performed similarly to the preparation of MB by elution with $8 \mathrm{~L}$ of $2 \mathrm{~N} \mathrm{NH}_{4} \mathrm{OH}$ (column; $200 \times 630 \mathrm{~mm}$ ). This eluate was concentrated to dryness and dissolved with $500 \mathrm{~mL}$ of distilled $\mathrm{H}_{2} \mathrm{O}$. This solution was chromatographed on an Amberlite CG-50 $\left(\mathrm{NH}_{4}{ }^{+}\right.$form $)$column $(55 \times 840 \mathrm{~mm})$ and fractionated by elution with distilled $\mathrm{H}_{2} \mathrm{O}$. The fraction containing DNJ was confirmed by TLC (chromatoplate; Silica Gel-60F 254 , developing solvent; $n-\mathrm{BuOH}$ : pyridine : $0.1 \mathrm{~N} \mathrm{HCl}=5: 3: 2$, color detection; ninhydrin reagent). This fraction was again applied to a column of Amberlite CG-50. The DNJ-containing fraction was concentrated and recrystallized with $70 \%$ methanol to afford a crystalline solid $(4.4 \mathrm{~g})$. This crystalline solid was analyzed by ${ }^{13} \mathrm{C}-\mathrm{NMR}\left(\mathrm{D}_{2} \mathrm{O}\right)$ and MS. The results were consistent with the values of DNJ in the literature.

Reagents. Sucrose, maltose, trehalose, and starch (soluble) were purchased from Wako Pure Chemical Industries, Ltd. (Osaka, Japan).

9-Fluorenyl-methylchloroformate and isomaltose were obtained from Sigma Chemical Co. (St. Louis, MO, USA).

Experimental animals. Male Wistar rats were purchased from Japan SLC Inc. (Hamamatsu, Japan) and kept in a wire-bottomed cage under a conventional lighting regimen with a dark night. The room temperature $\left(22 \pm 2^{\circ} \mathrm{C}\right)$ and humidity $(50 \pm 10 \%)$ were controlled automatically. Two rats were housed in each cage, and they were allowed ad libitum access to laboratory pellet chow (CE-2, CLEA Japan Inc., Tokyo, Japan) and tap water. After $1 \mathrm{wk}$ of acclimation, 8-wk-old rats were used for the postprandial hyperglycemia inhibition tests and 20-wk-old rats were used for the disaccharidase inhibition test.

All animal experiments were approved by the guidelines for animal experimentation of Kanagawa Prefectural Public Health Laboratories.

Carbohydrate loading with $M E$ and determination of blood glucose in rats. Screening of blood glucose levels after sucrose loading $(2 \mathrm{~g} / 10 \mathrm{~mL} / \mathrm{kg})$ was performed 2 wk before the experiments, and rats showing a blood glucose level of $160 \mathrm{mg} / \mathrm{dL}$ or above at $0.5 \mathrm{~h}$ after sucrose loading were used in the experiments. After overnight fasting, ME $(0.5,0.1$, and $0.02 \mathrm{~g} / 5 \mathrm{~mL} / \mathrm{kg}$, respectively) aqueous solution was given orally to 3 groups of rats (5-6 rats per group). At $0.5 \mathrm{~h}$ after ME administration, a carbohydrate solution was given orally. The carbohydrates used were sucrose, maltose, and soluble starch $(2 \mathrm{~g} / 10 \mathrm{~mL} / \mathrm{kg}$ each). The control group was given distilled $\mathrm{H}_{2} \mathrm{O}$ instead of the $\mathrm{ME}$ solution. Blood samples $(100 \mu \mathrm{L})$ were collected from the rat's tail vein at $0,0.5,1$, and $2 \mathrm{~h}$ after carbohydrate loading, and plasma glucose concentration was measured with Glucose II-HA Test Wako (Wako Pure Chemical Industries, Ltd., Osaka, Japan) using a clinical autoanalyzer (Super Z818, Nihon Monitor Inc., Tokyo, Japan). The ME dose showing 50\% inhibition of the increase in blood glucose $\left(\mathrm{ED}_{50}\right)$ was calculated.

Preparation of crude enzyme solution from small intestinal mucosa. Crude enzyme solution was prepared by the following modified method of Dahlqvist (12). The small intestine (the $20 \mathrm{~cm}$ of jejunal portion about $10 \mathrm{~cm}$ below the pylorus) was removed and the mucosa was gently scraped off with a slide glass. Mucosa from 10 animals was pooled and then (about $100 \mathrm{mg}$ )

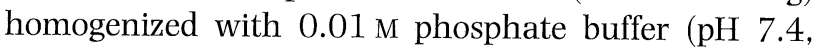
$2.0 \mathrm{~mL}$ ) using a Teflon homogenizer and centrifuged at $4^{\circ} \mathrm{C}$ for $10 \mathrm{~min}$ at $1,000 \times \mathrm{g}$. The supernatant was used for the assay of sucrase, maltase, isomaltase, and trehalase. Protein was measured by Lowry's method (13).

Disaccharidase inhibition test. For each test solution, serial dilutions were prepared with a substrate solution at a ratio of $10 \mathrm{in}$ the following range: $\mathrm{ME}, 0.2 \mu \mathrm{g} / \mathrm{mL}-$ $20 \mathrm{mg} / \mathrm{mL} ; \mathrm{MB}, 0.0348 \mu \mathrm{g} / \mathrm{mL}-3.48 \mathrm{mg} / \mathrm{mL}$; and DNJ, $0.001-100 \mu \mathrm{g} / \mathrm{mL}$. The substrate (sucrose, maltose, isomaltose, or trehalose; $10 \mathrm{~mm}$ each) was dissolved with $0.01 \mathrm{M}$ phosphate buffer. The sample-substrate mixture $(0.5 \mathrm{~mL})$ was added to the enzyme solution $(0.5 \mathrm{~mL})$ in test tubes and incubated at $37^{\circ} \mathrm{C}$ for $60 \mathrm{~min}$. The reaction was stopped by heating in a boiling bath for $5 \mathrm{~min}$. After the reaction mixture was cooled and centrifuged $(3,000 \mathrm{rpm}, 10 \mathrm{~min})$, the liberated glucose in the supernatant was measured as described above. As a control, the test solution was replaced with buffer solution. As a blank, buffer solution was used instead of substrate. In these enzyme inhibition tests, voglibose (Takeda Chemical Industries Ltd.) was used as the positive control.

The enzyme inhibition rate was calculated by comparison with the control. The concentration showing $50 \%$ enzyme inhibition $\left(\mathrm{IC}_{50}\right)$ was calculated by the Probit method.

$\alpha$-Amylase inhibition tests. Inhibitory activities on $\alpha$ amylase were measured using a commercial kit with human saliva-derived $\alpha$-amylase as the enzyme and carboxymethyl amylose as the substrate (Amylase B Test Wako, Wako Pure Chemical Industries, Ltd., Osaka, Japan). The $\mathrm{IC}_{50}$ values of $\mathrm{ME}$ and $\mathrm{MB}$ were calculated by a method similar to that in the disaccharidase inhibition tests.

Statistical analysis. Data are presented as the means \pm SEM. Statistical analyses were performed using one-way analysis of variance (one-way ANOVA). Differences among experimental and control groups were analyzed by the Dunnett's test and those at $p<0.05$ were accepted as significant.

\section{RESULTS}

Effects of ME on postprandial hyperglycemia in rats

The antihyperglycemic effects of ME after loading 

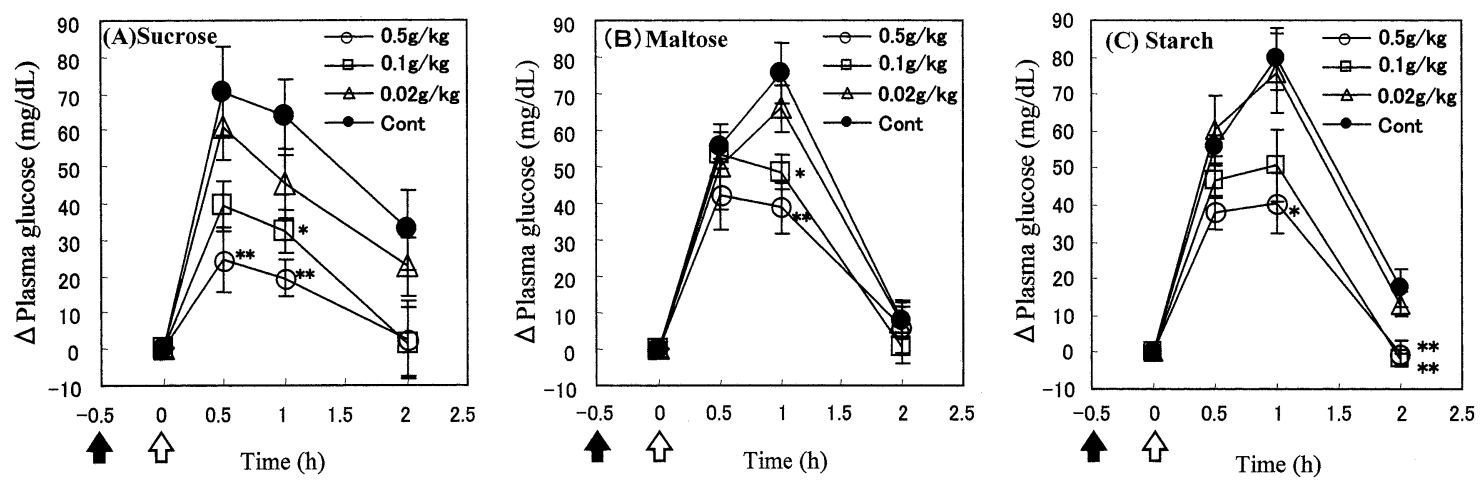

Fig. 1. Effects of the mulberry leaf extract (ME) pretreatment on plasma glucose after carbohydrate loading in normal rats. Overnight-fasted Wistar rats were given $2 \mathrm{~g} / \mathrm{kg}$ each carbohydrate(仓) after $0.5 \mathrm{~h} \mathrm{ME}(0.02-0.5 \mathrm{~g} / \mathrm{kg})$ by oral administra$\operatorname{tion}(\mathbf{)})$ and blood samples were taken at $0,0.5,1,2 \mathrm{~h}$ after the loading to determine plasma glucose. Values are the mean \pm SEM $(n=5-6)$ for the blood glucose increase in controls and ME treated rats. ${ }^{*} p<0.05,{ }^{* *} p<0.01$; ME-treated group vs control group.

Table 1. $\alpha$-Glucosidase inhibitory effects $\left(\mathrm{IC}_{50}\right)$ of the mulberry leaf extracts (ME) and their basic fractions $(\mathrm{MB})$.

\begin{tabular}{clrc}
\hline & Enzyme & $\mathrm{IC}_{50}(\mu \mathrm{g} / \mathrm{mL})$ & $\begin{array}{c}95 \% \text { confidence } \\
\text { limits }(\mu \mathrm{g} / \mathrm{mL})\end{array}$ \\
\hline \multirow{2}{*}{$\mathrm{ME}$} & Sucrase & 3.2 & $2.5-4.0$ \\
& Maltase & 51 & $39-65$ \\
& Isomaltase & 10 & $7.7-13$ \\
& Trehalase & 541 & $376-778$ \\
$\mathrm{MB}$ & Sucrase & 0.36 & $0.24-0.53$ \\
& Maltase & 6.2 & $4.8-8.0$ \\
& Isomaltase & 1.1 & $0.87-1.4$ \\
\multirow{2}{*}{$\mathrm{DNJ}$} & Trehalase & 100 & $72-139$ \\
& Sucrase & 0.015 & $0.010-0.023$ \\
& Maltase & 0.21 & $0.16-0.28$ \\
& Sucrase & 0.029 & $0.020-0.041$ \\
& Maltase & 0.65 & $0.40-1.1$ \\
\hline
\end{tabular}

DNJ, 1-deoxynojirimycin; Vog, Voglibose.

with sucrose, maltose, or starch were examined and the results are shown in Fig. 1. The blood glucose level before loading did not significantly differ among the groups $(87.8-118 \mathrm{mg} / \mathrm{dL})$. When the ME solution was orally administered $0.5 \mathrm{~h}$ before sucrose loading, the increase in blood glucose was significantly decreased at 0.5 and $1 \mathrm{~h}$ with $0.5 \mathrm{~g} / \mathrm{kg}$ of $\mathrm{ME}$ and at $1 \mathrm{~h}$ with $0.1 \mathrm{~g} /$ $\mathrm{kg}$ of ME compared with the control group (Fig. 1A). After maltose loading, significant depression was observed at $1 \mathrm{~h}$ with 0.5 and $0.1 \mathrm{~g} / \mathrm{kg}$ of $\mathrm{ME}$ and the value at $0.5 \mathrm{~h}$ tended to be lower with a dose of $0.5 \mathrm{~g} / \mathrm{kg}$ than in the control group (Fig. 1B). In starch loading, significant depression was observed at $1 \mathrm{~h}$ with $0.5 \mathrm{~g} /$ $\mathrm{kg}$ and at $2 \mathrm{~h}$ with 0.5 and $0.1 \mathrm{~g} / \mathrm{kg}$ of $\mathrm{ME}$ (Fig. 1C). Thus, ME dose-dependently suppressed the postprandial hyperglycemia after these carbohydrates were loaded. The $\mathrm{ED}_{50}$ of ME was $0.11 \mathrm{~g} / \mathrm{kg}$ for sucrose, $0.44 \mathrm{~g} / \mathrm{kg}$ for maltose, and $0.38 \mathrm{~g} / \mathrm{kg}$ for starch, respectively.

Inhibitory effects of $M E$ and $M B$ on small intestinal disaccharidase and salivary $\alpha$-amylase

The in vitro disaccharidase inhibitory actions of ME,
Table 2. $\quad \alpha$-Amylase inhibitory effects $\left(\mathrm{IC}_{50}\right)$ of the mulberry leaf extracts (ME) and their basic fractions (MB).

\begin{tabular}{lcc}
\hline & $\mathrm{IC}_{50}(\mu \mathrm{g} / \mathrm{mL})$ & $95 \%$ confidence limits $(\mu \mathrm{g} / \mathrm{mL})$ \\
\hline $\mathrm{ME}$ & 365 & $209-640$ \\
$\mathrm{MB}$ & 45.7 & $32.7-63.7$ \\
$\mathrm{DNJ}$ & 58.5 & $41.7-88.5$ \\
\hline
\end{tabular}

DNJ, 1-deoxynojirimycin.

$\mathrm{MB}$, DNJ, and voglibose were evaluated using enzyme solutions prepared from the rat small intestine. ME and MB dose-dependently inhibited the glucose formation from $5 \mathrm{~mm}$ of sucrose, isomaltose, maltose, or trehalose. Complete inhibition of the glucose formation from the carbohydrates tested was observed at $100 \mu \mathrm{g} / \mathrm{mL}$ of $\mathrm{ME}$ for sucrose and isomaltose, at $1,000 \mu \mathrm{g} / \mathrm{mL}$ of $\mathrm{ME}$ for maltose, at $10 \mu \mathrm{g} / \mathrm{mL}$ of $\mathrm{MB}$ for sucrose and isomaltose and at $100 \mu \mathrm{g} / \mathrm{mL}$ of $\mathrm{MB}$ for maltose.

The concentrations of $\mathrm{ME}$ and $\mathrm{MB}$ needed for $50 \%$ inhibition $\left(\mathrm{IC}_{50}\right)$ of sucrase, maltase, isomaltase and trehalase are shown in Table 1 . The most potent inhibition by $\mathrm{ME}$ and $\mathrm{MB}$ was observed with sucrase. The $\mathrm{IC}_{50}$ value of ME was $3.2 \mu \mathrm{g} / \mathrm{mL}$ for sucrase, $10 \mu \mathrm{g} / \mathrm{mL}$ for isomaltase, $51 \mu \mathrm{g} / \mathrm{mL}$ for maltase, and $541 \mu \mathrm{g} / \mathrm{mL}$ for trehalase, respectively. The $\mathrm{IC}_{50}$ value of $\mathrm{MB}$ was $0.36 \mu \mathrm{g} / \mathrm{mL}$ for sucrase, $1.1 \mu \mathrm{g} / \mathrm{mL}$ for isomaltase, $6.2 \mu \mathrm{g} / \mathrm{mL}$ for maltase, and $100 \mu \mathrm{g} / \mathrm{mL}$ for trehalase, respectively (Table 1 ). The $\mathrm{IC}_{50}$ value of $\mathrm{DNJ}$ was $0.015 \mu \mathrm{g} / \mathrm{mL}$ for sucrase and $0.21 \mu \mathrm{g} / \mathrm{mL}$ for maltase, whereas that of voglibose as the positive control was $0.029 \mu \mathrm{g} / \mathrm{mL}$ for sucrase and $0.65 \mu \mathrm{g} / \mathrm{mL}$ for maltase. The $\mathrm{IC}_{50}$ values of $\mathrm{ME}, \mathrm{MB}$, and $\mathrm{DNJ}$ for human salivaderived amylase were $365,45.7$, and $58.5 \mu \mathrm{g} / \mathrm{mL}$, respectively (Table 2 ).

\section{DISCUSSION}

This study showed that the pretreatment of rats with ME significantly suppressed the increase in plasma glucose level after loading with sucrose, maltose or starch and the most potent suppressive effect of ME was 
observed with sucrose. The study also showed that ME had the most potent inhibitory effect on sucrase among 4 types of disaccharidase derived from the rat small intestine. The inhibitory activities of ME for isomaltase, maltase, and trehalase were $1 / 3,1 / 16$, and $1 / 170$ of that for sucrase, respectively. These inhibitory effects of ME on sucrase and maltase were more than 800 times and about 30 times higher than those of hot-water extracts from guava leave (14) in terms of the amount corresponding to yield.

It has been reported that the active components in mulberry leaves exhibiting an inhibitory effect on $\alpha$ glucosidase are nitrogen-containing sugars such as DNJ $(2,5,6)$. In our experiment, the concentration of DNJ was $1.1 \%$ in $\mathrm{ME}$ and $6.32 \%$ in $\mathrm{MB}$. The $\mathrm{IC}_{50}$ values of $\mathrm{ME}$ and $\mathrm{MB}$ were 3.2 and $0.36 \mu \mathrm{g} / \mathrm{mL}$ for sucrase and 51 and $6.2 \mu \mathrm{g} / \mathrm{mL}$ for maltase, respectively. These values correspond to 0.035 and $0.023 \mu \mathrm{g} / \mathrm{mL}$ of $\mathrm{DNJ}$ for sucrase and 0.56 and $0.39 \mu \mathrm{g} / \mathrm{mL}$ of DNJ for maltase. Therefore, this indicates that the inhibitory effects of $\mathrm{ME}$ and $\mathrm{MB}$ on small intestinal disaccharidase are principally due to $\mathrm{DNJ}$, since the $\mathrm{IC}_{50}$ value of $\mathrm{DNJ}$ was $0.015 \mu \mathrm{g} / \mathrm{mL}$ for sucrase and $0.21 \mu \mathrm{g} / \mathrm{mL}$ for maltase.

ME and MB had only a slight inhibitory effect on the $\alpha$-amylase of human saliva. However, since ME and MB strongly inhibited isomaltase activity (Table 1), these extracts are considered to participate in the inhibitory digestion of isomaltose formed from $\alpha$-limit dextrin as a partial hydrolysate of starch.

As shown in Fig.1, ME had the most potent suppressive effect on postprandial hyperglycemia by loading sucrose, followed in order by starch and maltose. In the in vitro experiment of small intestinal disaccharidase inhibition, ME showed marked inhibition of sucrase. Therefore, the antihyperglycemic effect of ME after sucrose loading may be produced by the inhibition of sucrase in the small intestine, resulting in the suppression of the blood glucose increase.

Borderline diabetes mellitus is characterized by a fasting glucose value close to normal but an abnormal postprandial glucose value. An abnormal postprandial glucose increase in the plasma stimulates insulin secretion, imposing an excessive, exhausting burden on $\beta$ cells in the islets of Langerhans. Prophylactic administration of $\alpha$-glucosidase inhibitors has been suggested to inhibit or prevent the development of diabetes mellitus (15). From these aspects, ME might be beneficial for the prevention of human diabetes by suppressing intestinal $\alpha$-glucosidase activities.

\section{REFERENCES}

1) Kimura M, Chen FJ, Nakashima N, Kimura I, Asano N, Koya S. 1995. Antihyperglycemic effects of N-containing sugars derived from mulberry leaves in streptozocin- induced diabetic mice. J Traditional Med 12: 214-219.

2) Chen FJ, Nakashima N, Kimura I, Kimura M, Asano N, Koya S. 1995. Potentiating effects on Pilocarpineinduced saliva serection, by extracts and N-containing sugars derived from mulberry leaves, in streptozocininduced diabetic mice. Biol Pharm Bull 18: 1676-1680.

3) Kojima Y, Tonegawa E, Taniguchi K, Narasaki R, Hasumi K. 2001. Retardation of the development of diabetes mellitus in a murine model of type 1 diabetes (NOD mouse) fed Morus alba leaves. Nippon Eiyo Shokuryo Gakkaishi (J Jpn Soc Nutr Sci) 54: 361-364 (in Japanese).

4) Miyahara C, Satoh S, Miyazawa M, Horiguchi Y, Shimizu A, Harada M. 1996. Antihyperglycemic effects of mulberry leaves in spontaneous diabetic rats. A report of a joint research project on functional food materials (Kanagawa Prefecture) No. 2, 52-59 (in Japanese).

5) Yoshikuni Y. 1988. $\alpha$-Glucosidase activity and postprandial hyperglycemia by Moranoline and its N-Alkyl derivatives. Agric Biol Chem 52: 121-128.

6) Asano N, Tomioka E, Kizu H, Matsui K. 1994. Sugars with nitrogen in ring isolated from the leaves of Morus bombycis. Carbohydrate Res 253: 235-245.

7) A Report of the Present Status Survey, Ministry of Health and Welfare, Tokyo, Japan, March 1998.

8) Odaka H, Shino A, Ikeda H, Matsuo T. 1992. Antiobesity and antidiabetic actions of a new potent disaccharidase inhibitor in genetically obese-diabetic mice, KKAy. J Nutr Sci Vitaminol 38: 27-37.

9) Miura T, Koide T, Ohichi R, Kako M, Usami M, Ishihara E, Yasuda N, Ishida H, Seino Y, Tanigawa K. 1998. Effect of Acarbose ( $\alpha$-glicosidase inhibitor) on disaccharase activity in small intestine in KK-Ay and ddY mice. J Nutr Sci Vitaminol 44: 371-379.

10) Odaka H, Miki N, Ikeda H, Matsuo T. 1992. Effects of disaccharidase inhibitor, AO-128, on postprandial hyperglycemia in rats. Nippon Eiyo Shokuryo Gakkaishi (J Jpn Soc Nutr Sci) 45: 27-31 (in Japanese).

11) Cole MD, Fellows LE. 1988. Separation of polyhydroxy derivatives of 2-carboxy and 2-hydroxymethyl piperidine and pyrrolidine by high-performance liquid chromatography. J Chromat 445: 295.

12) Dahlqvist A. 1968. Assay of intestinal disaccharidases. Anal Biochem 22: 99-107.

13) Lowry OH, Rosebrough NJ, Farr AL, Randal RJ. 1951. Protein measurement with the Folin phenol reagent. J Biol Chem 193: 265-275.

14) Deguchi Y, Osada K, Uchida K, Kimura H, Yoshikawa M, Kudo T, Yasui H, Watanuki M. 1998. Effects of guava leaves on the development of diabates in the $\mathrm{db} / \mathrm{db}$ mouse and on the postprandial blood glucose of human subjects. Nippon Nougeikagaku Kaishi 72: 923-931(in Japanese).

15) Akiyama T, Kanda K, Yoshikawa H, Hirohata Y, Kihara Y, Nakamura H, Otsuki M. 2002. $\alpha$-Glucosidase inhibitor prevents the development of impaired glucose tolerance in type 2 diabetes. J Japan Diab Soc 45: 791-795 (in Japanese). 